\title{
Internalisasi Nilai-nilai Multikultural dalam Tafsîr Al-R̄̄zi pada Pengembangan Pendekatan Pembelajaran Tafsir
}

\author{
Moh.Noor. Hidayat \\ MAN Model Palangka Raya \\ hidayatnoormoh@gmail.com
}

\begin{abstract}
This article contains about study of multicultural values in the tafsîr Imām Fakhruddîn Al-Rāzî (Mafätîhul Ghaib), which has different specification from other tafsir in the same era. It includes many arguments about theology and fiqh. Furthermore, the multicultural values in this tafsîr are implemented on the development approach of learning tafsîr. This study used library research with phenomenology approach by seeing the reality of tafsîr Imām Fakhruddîn Ar-Rāzî which is accepted and refered by many of firqah, besides tafsîr Maudhu' 'i is used tool to make the study of tafsir Imām Fakhruddîn Ar-Rāzî deeper. The result of this study consist of two parts: 1) An explanation of multicultural values concepts in tafsîr Mafātîhul Ghaib, 2) Multicultural approach learning as the result of implementing multicultural values on learning approach.
\end{abstract}

Keywords: Internalitation, Multicultural values, Tafsîr Al-Rāzi, Approach of learning

\section{A. Pendahuluan}

Istilah multikulturalisme yang muncul sekitar tahun 1970-an di Kanada, Australia, Amerika Serikat, Inggris dan Jerman, ${ }^{1}$ menjadi isu aktual yang diperbincangkan dalam berbagai perspektif pada dekade ini, terutama perspektif pendidikan, di samping perspektif politik, psikologi, sosiologi, antropologi, dan hukum. Ini disebabkan banyaknya diskriminasi dalam dunia pendidikan yang bermuara pada masalah multikultural, seperti diadakannya sekolah RSBI $^{2}$ yang hanya menerima siswa dengan kemampuan akademi dan ekonomi tertentu saja, kemudian adanya sekolah yang tidak menerima siswa dengan kekurangan fisik, serta banyak lagi permasalahan diskriminasi yang lain. Namun, Islam melalui AlQur'ān sebenarnya sudah sejak 14 abad yang silam mengemukakan tentang multikulturalisme, ${ }^{3}$ dibuktikan dengan ajaran Islam mengenai persamaan derajat, lalu ajaran mengenai hidup dalam perbedaan, seperti yang tertulis di surah AlḤujurāt ayat 13, yang artinya:

\footnotetext{
${ }^{1}$ H.A.R Tilaar, Multikulturalisme: Tantangan-tantangan Global Masa Depan dalam Transformasi Pendidikan Nasional, Jakarta: Grasindo, 2004, h. 84.

${ }^{2}$ RSBI (Rintisan Sekolah Berstandar Internasional).

'Jamalul Banna, At-Ta'addudiyyah Fî Mujtama' Islamî, Qohiroh: Dar Al-Fikr Al-Islamiy, 2001, h. 10.
} 
"Wahai manusia! Sesungguhnya, Kami telah menciptakan kamu dari seorang laki-laki dan seorang perempuan, kemudian Kami jadikan kamu berbangsa-bangsa dan bersuku-suku agar kamu saling mengenal. Sesungguhnya orang yang paling mulia di antara kamu di-sisi Allah ialah orang yang paling bertakwa di antara kamu. Sesungguhnya Allah Maha Mengetahui lagi Maha Teliti. ${ }^{4}$

Kemudian di dalam surah Al-Māidah ayat 48, yang artinya:

"Dan Kami telah menurunkan Kitab (Al-Qur'ān) kepadamu (Muhammad) dengan membawa kebenaran, membenarkan kitab-kitab yang diturunkan sebelumnya dan menjaganya, maka putuskanlah perkara mereka menurut apa yang diturunkan Allah dan janganlah kamu mengikuti hawa nafsu mereka dengan meninggalkan kebenaran yang telah datang kepadamu. Untuk tiap-tiap umat di antara kamu, Kami berikan aturan dan jalan yang terang. Sekiranya Allah menghendaki, niscaya kamu dijadikan-Nya satu umat (saja), tetapi Allah hendak menguji kamu terhadap pemberian-Nya, maka berlomba-lombalah berbuat kebajikan. Hanya kepada Allah-lah kamu semua akan kembali, lalu diberitahukan-Nya kepadamu apa yang telah kamu perselisihkan". 5

Selain ajaran mengenai persamaan derajat dan mengenai hidup dalam perbedaan, masih banyak lagi nilai-nilai multikulturalisme yang dikemukakan di dalam Al-Qur'ān, di antaranya toleransi pada surah Yunūs ayat 41, menghargai pendapat pada surah Al-Baqarah ayat 256, beretika dalam pergaulan pada surah Al-Hujurāt ayat 11, dan banyak lagi yang lainnya. Lebih luas lagi, multikulturalisme di dalam Al-Qur'ān tidak hanya dikemukakan secara tersurat saja, tetapi dikemukakan juga secara tersirat. Sebab luasnya makna yang terkandung di dalam $u s l \bar{u} b^{6}$ Al-Qur'ān. ${ }^{7}$ Adapun untuk memahami uslūb AlQur'ān secara rinci tidaklah cukup hanya dengan membacanya, akan tetapi perlu dilakukan kajian secara sistematik, radikal dan mendalam melalui penafsiran AlQur'ān. ${ }^{8}$

Dalam usaha menafsirkan ayat-ayat Al-Qur'ān yang memuat permasalahan multikultural, seorang mufassîr tidak hanya dituntut memiliki

\footnotetext{
${ }^{4}$ Wahbah Zuhaili, Al-Mausū'atul Qur'āniyyatul Muyassarah, Depok: Gema Insani, 1428 H/ 2007 M, Cet. ke-1, Al-Hujurāt [49]:13, h. 518.

${ }^{5}$ Ibid., Al-Māidah [5]:48, h. 117.

${ }^{6}$ Susunan kata.

${ }^{7}$ Jamalul Banna, At-Ta'addudiyyah Fî Mujtama' Islamî, h. 10.

${ }^{8}$ Yusuf Al-Qardhawi, Aqidah Salaf dan Khalaf, Jakarta: Pustaka Al-Kautsar, 2006, Cet.
} ke-I, h. 22. 
pengetahuan dan wawasan yang luas dalam berbagai disiplin ilmu, akan tetapi juga dituntut memiliki sikap objektif. Karena sikap subjektif pada penafsiran AlQur'ān hanya akan menjebak seorang mufassîr kepada sikap mendiskreditkan pemahaman orang lain, parahnya sikap ini mendorong munculnya doktrin saling mengkafirkan yang pada akhirnya akan menggiring ke arah perpecahan. Isu ini juga yang menyebabkan munculnya banyak golongan di dalam teologi Islam. ${ }^{9}$

Dari sekian banyak mufassîr dengan berbagai macam pemahamannya, terdapat seorang mufassîr bernama Imām Fakhruddîn Ar-Rāzî yang berhasil membuat inovasi dengan memformulasikan berbagai pemahaman di dalam tafsîrnya yang berjudul Mafâtîhul Ghaib. Sehingga kitab tafsîr yang ditulisnya bisa diterima oleh semua golongan. Bahkan Imām Fakhruddîn Ar-Rāzî diakui sebagai guru tafsîr untuk semua golongan. Fakta bahwa Imām Fakhruddîn ArRāzî merupakan guru dari semua golongan dibuktikan dengan diangkatnya beliau $^{10}$ sebagai guru kehormatan di kota Ghaznah ${ }^{11}$ oleh Raja Ghaznah yaitu Shihabuddin Al-Ghurri. Padahal Raja Shihabuddin dan mayoritas penduduk kota Ghaznah adalah penganut paham Karramîyah, ${ }^{12}$ berbeda dengan Imām Fakhruddîn Ar-Rāzî yang menganut paham Asy'âriyah. ${ }^{13}$ Selain itu, di dalam kitab tafsîrnya Imām Fakhruddîn Ar-Rāzî tidak hanya menjabarkan pendapatpendapat dari Asy'âriyah saja, tetapi juga mengemukakan pendapat-pendapat Mu'tazilah, ${ }^{14}$ Jabariyah, $^{15}$ Qadariyah $^{16}$ dan lain-lain. Bahkan ketika beliau

${ }^{9}$ Sahilun A. Nasir, Pemikiran Kalam (Teologi Islam): Sejarah, Ajaran dan Perkembangannya, Jakarta: Raja Grafindo Persada, 2010, Cet. ke-I, h. 34.

${ }^{10}$ Makna dari kata beliau adalah dia (dipakai untuk orang tua atau orang yg patut dihormati), dan kata beliau pada tulisan ini merujuk kepada Imām Fakhruddîn Ar-Rāzî. Kamus Besar Bahasa Indonesia, Jakarta: Pusat Bahasa DEPDIKNAS, 2008, h. 167. Afghanistan.

${ }^{11}$ Ghaznah adalah kota yang terletak di antara Kabul dan Kandahar di wilayah

${ }^{12}$ Karamiyyah adalah suatu aliran di dalam ilmu kalam yang menganut paham ajaran Muhammad bin Karam.

${ }^{13}$ Asy'ariyah adalah suatu aliran di dalam ilmu kalam yang menganut paham ajaran Abu Hasan Al-Asy'ari.

${ }^{14} \mathrm{Mu}$ 'tazilah adalah suatu aliran di dalam ilmu kalam yang menganut paham ajaran Washil bin Atha'.

${ }^{15}$ Jabariyah adalah suatu sekte atau aliran di dalam ilmu kalam yang menganut paham ajaran Ja'ad bin Dirham dan Jahm bin Shafwan.

${ }^{16}$ Qadariyah adalah suatu sekte atau aliran di dalam ilmu kalam yang menganut paham ajaran Ma'ad Al-Jauhani dan Ghailan Ad-Dimasyqy. 
menjelaskan ayat-ayat $a h k \bar{a} m,{ }^{17}$ Imām Fakhruddîn Ar-Rāzî tidak pernah lupa untuk mengungkapkan pendapat dari empat mazhab fikih. ${ }^{18}$

Apa yang telah diteladankan oleh Imām Fakhruddîn Ar-Rāzî dari sikap respek terhadap kemajemukan yang tergambar di dalam tafsîrnya dan pada pembelajaran tafsîr, merupakan hal yang patut diteladani pada pembelajaran tafsîr saat ini, sebab keadaan yang dihadapi oleh seorang guru saat ini hampir sama dengan keadaan yang dihadapi oleh Imām Fakhruddîn Ar-Rāzî, yaitu menghadapi peserta didik dengan latar belakang yang berbeda-beda. Adapun dalam proses pengenalan tafsîr Al-Qur'ān kepada peserta didik, perbedaan latar belakang peserta didik merupakan hal yang perlu diperhatikan. Sebab perbedaan latar belakang peserta didik akan sangat berpengaruh terhadap pemahaman dari tafsîr Al-Qur'ān. Contoh konkret dari perbedaan pemahaman yang terjadi di antara peserta didik adalah ketika menafsirkan ayat tentang taqdir, para peserta didik yang berpegang pada pemikiran modern akan menyatakan bahwa Allah SWT menentukan taqdir seseorang sesuai dengan apa yang diusahakannya, akan tetapi sebaliknya para peserta didik yang berpegang dengan pemikiran sufi akan menyatakan bahwa Allah SWT sudah menentukan taqdir seseorang sejak di dalam perut ibunya. Oleh karena itu, untuk menyikapi perbedaan persepsi yang terjadi dan diharapkan bisa memberikan solusi yang terbaik, maka dalam proses pembelajaran tafsîr seorang guru harus menggunakan pendekatan pembelajaran yang mengandung nilai-nilai multikultural sebagaimana yang dicontohkan oleh Imām Fakhruddîn Al-Rāzî.

Berdasarkan paparan ini, terdapat beberapa hal yang menarik, sehingga dilakukan telaah lebih dalam, karena memiliki manfaat yang sangat urgen mengenai masalah nilai-nilai multikultural dan pendekatan pembelajaran tafsîr, yaitu bagaimana konsep nilai-nilai multikultural yang diungkap oleh Imām Fakhruddîn Ar-Rāzî di dalam tafsîrnya? Mengingat beliau dianggap sebagai seorang mufassîr yang objektif dan berhasil mengakomodasi berbagai pemahaman. Kemudian, bagaimana internalisasi dari konsep nilai-nilai

\footnotetext{
${ }^{17}$ Ayat-ayat yang bertalian dengan berbagai macam hukum di dalam Al-Qur'an.

${ }^{18}$ Muhammad bin Umar, Mafātîhul Ghaib, Beirut: Dar Al-Kotob Al-Ilmiyah, 1434 H/ 2013 M, Juz. 1, h. 5.
} 
multikultural tersebut pada pengembangan pendekatan pembelajaran tafsîr? Mengingat nilai-nilai multikultural yang diungkap oleh Imām Ar-Rāzî di dalam tafsirnya dan yang diaplikasikannya pada pembelajaran tafsir dapat dijadikan sebagai role model dalam pengembangan pendekatan pembelajaran tafsîr. Pertanyaan-pertanyaan inilah yang mendorong dilakukannya kajian dan bahasan tentang internalisasi nilai-nilai multikultural tafsîr Ar-Rāzî dalam pengembangan pendekatan pembelajaran tafsîr.

\section{B. Kajian Pustaka}

Menurut Muhammad Yusri FM, terdapat tiga istilah yang sering dipakai dalam menggambarkan keragaman di masyarakat, yaitu pluralitas (plurality), keragaman (diversity) dan multikultural (multicultural). ${ }^{19}$ Ketiga istilah ini merepresentasikan hal yang sama yaitu keadaan lebih dari satu atau jamak. Lebih lanjut, Farida Hanum dan Setya Raharja menjelaskan bahwa keragaman itu berpengaruh terhadap tingkah laku, sikap dan pola pikir manusia, sehingga manusia memiliki cara-cara (usage), kebiasaan (folk ways), aturan-aturan (mores) bahkan adat istiadat (customs) yang berbeda. ${ }^{20}$ Apabila keadaan ini tidak dapat dipahami dengan baik, maka akan sangat rawan terjadi pergesekan yang kemudian berbuah pada adanya konflik. Sedangkan istilah multikulturalisme terbentuk dari tiga kata, yaitu multi (banyak), kultur (budaya), isme (aliran atau paham). Sehingga multikulturalisme dapat diartikan sebagai aliran atau paham tentang banyak budaya atau keberagaman budaya. ${ }^{21}$

Sementara itu menurut Parekh di dalam Farida Hanum dan Setya Raharja, pengertian dari multikulturalisme meliputi tiga hal, yaitu: Pertama, multikulturalisme berkenaan dengan budaya; Kedua, merujuk pada keragaman yang ada; Ketiga, berkenaan dengan tindakan spesifik pada respon terhadap keragaman tersebut. Akhiran "isme" menunjukkan suatu doktrin normatif yang

\footnotetext{
${ }^{19}$ Muhammad Yusri FM, "Prinsip Pendidikan Multikulturalisme dalam Ajaran Agamaagama di Indonesia", Jurnal Kependidikan Islam Jurusan Kependidikan Islam Fakultas Tarbiyah UIN Sunan Kalijaga Yogyakarta, Vol. 3, No. 2, 2008, h. 1.

${ }^{20}$ Farida Hanum dan Setya Raharja, "Pengembangan Model Pembelajaran Pendidikan Multikultural Menggunakan Modul Sebagai Suplemen Pelajaran IPS di Sekolah Dasar", Jurnal Penelitian Ilmu Pendidikan, Vol. 04, No. 2, 2011, h. 114.

${ }^{21}$ H.A.R Tilaar, Multikulturalisme: Tantangan-tantangan, h. 82.
} 
diharapkan bekerja pada setiap orang dengan konteks masyarakat majemuk. ${ }^{22}$ Adapun Musa Asy'arie dalam Choirul Mahfud berpendapat bahwa multikulturalisme adalah kearifan untuk melihat keanekaragaman budaya sebagai realitas fundamental dalam kehidupan bermasyarakat. ${ }^{23}$ Kearifan itu segera muncul, jika seseorang membuka diri untuk menjalani kehidupan bersama dengan melihat realitas plural sebagai kemestian hidup yang kodrati, baik dalam kehidupan pribadi yang multidimensi, maupun dalam kehidupan masyarakat yang kompleks, dan karenanya muncul kesadaran bahwa keanekaragaman dalam realitas dinamika kehidupan adalah suatu keniscayaan yang tidak bisa ditolak, diingkari, apalagi dimusnahkan.

Menurut H.A.R Tilaar, nilai-nilai multikultural yang diterapkan sebagai indikasi menerima realitas keragaman terdiri dari: Belajar hidup dalam perbedaan; Membangun saling percaya (mutual trust); Memelihara saling pengertian (mutual understanding); Menjunjung sikap saling menghargai (mutual respect); Terbuka dalam berpikir; Apresiasi dan interdepedensi; Resolusi konflik; Rekonsiliasi tanpa kekerasan. ${ }^{24}$

Menurut Imam Al-Gazali, hadîs ini memberikan arahan bahwa dalam pembelajaran hendaknya seorang guru memperhatikan kemampuan peserta didiknya dalam menyampaikan apa yang diajarkannya, ${ }^{25}$ sebab apabila guru menyampaikan sesuatu yang tidak sesuai dengan kadar kemampuan penerimanya, ditakutkan akan terjadi kesalahpahaman. Hal ini dipertegas dengan hadîs baginda Rasul SAW, yang artinya:”Sabda Rasulullah SAW: “tidaklah seseorang berbicara kepada suatu kaum dengan perkataan yang tidak mereka pahami, kecuali akan menimbulkan fitnah bagi mereka". ${ }^{26}$

Menurut Mannā' Al-Qottōn, Imām Ar-Rāzî mempunyai banyak gelar, yang paling terkenal diantaranya adalah Ibnu Al-Khatib, Ibnu Khatib Al-Ray, Abî Abdillah, Abil Fadl, Abil Ma'ali. ${ }^{27}$ Sejumlah gelar yang disematkan kepada beliau

\footnotetext{
${ }^{22}$ Farida Hanum dan Setya Raharja, Pengembangan Model Pembelajaran, h. 115.

${ }^{23}$ Choirul Mahfud, Pendidikan Multikultural, Yogyakarta: Pustaka Pelajar, 2008, h.103.

${ }^{24}$ H.A.R Tilaar, Multikulturalisme: Tantangan-tantangan, h. 84.

${ }^{25}$ Muhammad Al-Gazali, Ihya Ulümuddîn, Beirut: Dar Al-Ma'rifah, t.th, Juz. 1, h. 57.

${ }^{26}$ Ibid., h. 99.

${ }^{27}$ Manna' Kholil Al-Qotton, Mabāhis fì 'Ulūm Al-Qur'ān, h. 387.
} 
tersebut, merupakan suatu bentuk penghormatan yang diberikan oleh banyak orang sebab keluasan ilmu yang belau miliki. Pada statusnya sebagai mufassîr, beliau sangat terkenal dengan nama Fakhruddîn Ar-Rāzî atau Fakhrūr Rāzî. Imām Ar-Rāzî dilahirkan pada tahun 544H di kota Al-Ray ${ }^{28}$, wafat pada tahun $606 \mathrm{H}$ di kota Harrah. $^{29}$ Menurut satu pendapat, wafatnya beliau disebabkan sikap permusuhan dengan golongan Karramîyah yang menuduh Imām Ar-Rāzî sebagai orang kafir dan telah melakukan dosa besar. Pendapat lain menyebutkan bahwa sebab wafatnya beliau adalah karena diracuni. ${ }^{30}$ Terlepas dari kontroversi tentang kewafatannya, Imām Fakhruddîn Ar-Rāzî merupakan seorang ulama yang menguasai berbagai macam disiplin ilmu secara komprehensif. Hal ini tergambar dari tulisan beliau di dalam tafsîr Mafātîhul Ghaib yang memuat berbagai macam disiplin ilmu, baik ilmu fiqih, ușul, naḥwu, balagah, astronomi, kedokteran, dan lain sebagainya, bahkan Abu Hayyan menyebutkan bahwa Imām Fakhruddîn ArRāzî mengumpulkan segala hal secara terperinci di dalam tafsirnya. Sehingga tidaklah aneh, apabila kitab tafsîr Mafātîhul Ghaib dijadikan sebagai rujukan oleh banyak orang dari berbagai latar belakang.

Imām Ar-Rāzî mempelajari berbagai macam ilmu dari beberapa guru yang sangat beliau hormati. Adapun guru pertama beliau adalah ayahnya sendiri yang bernama Diyāuddîn Umar bin Ḥusain Khatib Al-Ray, dan sebagian besar ilmuilmu yang dikuasai oleh Imām Ar-Rāzî didapatkan dari ayahnya, seperti ilmu uṣul, ilmu kalām dan ittibā' dalam bermadzhab. Hal ini yang menyebabkan beliau seringkali menyebut nama ayahnya dalam kitab tafsirnya. ${ }^{31}$ Setelah ayahnya wafat beliau berguru kepada Imām Al-Kamāl As-Sam'ānî. Selanjutnya mempelajari ilmu hikmah kepada Al-Majd Al-Jaily di-Marāgî, dan mempelajari ilmu filsafat dari buku-buku Aristoteles, Plato, Ibnu Sina dan Al-Farabi, sehingga beliau tidak hanya menguasai ilmu syari'at Islām saja, akan tetapi beliau juga menguasai ilmu hikmah dan juga ilmu kalām.

\footnotetext{
${ }^{28}$ Ray merupakan salah satu kota yang ada di provinsi Teheran (Iran) dan merupakan kota tua yang masih bertahan.

${ }^{29}$ Harrah adalah nama suatu kota di Suriah.

${ }^{30}$ Muhammad Husein Adz-Dzahabi, At-Tafsîr wal Mufassîrūn, Qohiroh: Maktabah Wahbah, 1396H/ 1976M, Juz. 1, h. 207.

${ }^{31}$ Ibid.
} 
Berkaitan dengan ilmu kalām, beliau terhitung sebagai ulama ahli kalām yang paling terkenal dalam madzhab Asy'ari. Sehingga terdapat statemen yang menyatakan bahwa beliau hampir setingkat bahkan melampaui Imam Asy’āri dan Imam Syafi'î, karena beliau sering menjawab beberapa permasalahan yang terdapat dalam ilmu kalām dan ilmu fiqh, ${ }^{32}$ seperti permasalahan tentang esensi dan eksistensi Al-Qurān.

Selain Imām Ar-Rāzî mendapat kepercayaan dan pujian dari beberapa 'ulama, beliau juga mendapat kecaman dan celaan dari beberapa 'ulama yang lain. Di antara ulama yang anti terhadapnya adalah Al-Hafiz Aż-Żahabî, beliau mengatakan bahwa Imām Ar-Rāzî adalah sang pemikir yang sangat cerdas, tetapi sayangnya telah menyelewengkan beberapa permasalahan yang sifatnya substansial dalam agama. Lebih jauh, Imām Al-Hafiz mengatakan bahwa salah satu karangan Ar-Rāzî yang berjudul "Al-sirrul Maktum Fî Mukhatabatin Nujŭm" (rahasia yang tersembunyi dalam perbincangan bintang-bintang) adalah sebuah karya sihir. ${ }^{33}$ Ditambahkan oleh Aṣ-Șadafi, bahwa Imām Fakhruddîn Ar-Rāzî adalah seseorang yang telah berpaling dari sunah dan lebih mengikut kepada ajaran-ajaran Ibnu Sina dan Aristoteles. ${ }^{34}$

Adapun ulama yang sangat mencintai Al-Rāzî dan memastikan bahwa beliau tidak menyimpang dari syari'at juga cukup banyak. Di antara mereka adalah Imam Muhyiddīn Ibnu 'Arabî, yang pada masa itu merupakan tokoh sufi terbesar serta lebih dari 106 ulama menganggap bahwa Ar-Rāzî adalah orang yang telah mampu memberikan pembaharuan dan nuansa baru dalam agama. Maka tidak heran jika peranan dan posisi beliau yang menjadi panutan umat menumbuhkan sebuah kecemburuan dan rasa iri hati di kalangan orang yang tidak setuju atau antipati terhadapnya. ${ }^{35}$ Membanding dari berbagai referensi dan pendapat 'ulama mengenai sosok Ar-Rāzî, maka akan ditemukan lebih banyak pengakuan terhadap kelebihannya dari pada penjelasan terhadap kekurangannya.

\footnotetext{
${ }^{32}$ Muhammad Ali As-Shabuni, At-Tibyan Fî̀ 'Ulūmil Qur'ān, Karachi: Maktabah AlBushra, 1432H/ 2011M, h. 137.

${ }^{33}$ Ibid, h. 653.

${ }^{34}$ Ibid.

${ }^{35}$ Ibid.
} 
Hal ini merupakan buah dari apa yang telah disumbangkan Ar-Rāzî, baik dari karya-karyanya atau pengajaran-pengajarannya. Adapun sikap sebagian kecil 'ulama yang antipati terhadapnya merupakan hal yang wajar, mengingat di antara sifat manusia terdapat sikap cemburu dan iri hati.

Adapun tafsîr Mafātîhul Ghaib atau yang dikenal sebagai tafsîr Al-Kabîr karya Imām Fakhruddîn Ar-Rāzî adalah kitab tafsir yang berkategori sebagai tafsîr bir ra'yi (tafsir yang menggunakan pendekatan akal), dengan pendekatan Mazhab Syāfi'iyyah dan Asy'āriyah. Tafsîr ini merujuk pada kitab Az-Zūjāj fî Ma'ānil Qurān, Al-Farra' wal Barra dan Gharībul Qurān, karya Ibnu Qutaibah dalam masalah gramatika. ${ }^{36}$ Riwayat-riwayat tafsîr bil ma'tsur yang jadi rujukan adalah riwayat dari Ibnu Abbās, Mujāhid, Qatadah, Sudai, Sa'id bin Jubair,

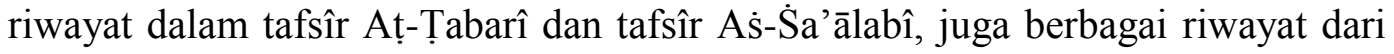
Nabi SAW, keluarga, para sahabatnya serta tabi'in. ${ }^{37}$ Sedangkan tafsîr bir ra'yi yang jadi rujukan adalah tafsîr Abū 'Alî Al-Juba'i, Abū Muslim Al-Aṣfiḥanni, Qaḍi Abdul Jabbār, Abū Bakar Al-Așmam, 'Alî bin 'Īsa Ar-Rumaini, AzZamakhsyarî dan tafsîr Abul Futūh Ar-Rāzî. ${ }^{38}$

Tujuan ditulisnya tafsîr ini dengan segala uraiannya, antara lain: Pertama; menjaga dan membersihkan Al-Qur'ān beserta segala isinya dari kecenderungankecenderungan rasional, dengan hal ini diupayakan bisa memperkuat keyakinan terhadap Al-Qur'ān. Kedua; mengungkap pembuktian eksistensi Allah swt dengan dua hal. Yaitu "bukti terlihat", dalam bentuk wujud kebendaan dan kehidupan, serta "bukti terbaca”, dalam bentuk Al-Qur'ān. Apabila merenungi hal yang pertama secara mendalam, maka akan semakin memahami hal yang kedua. Karena itu Ar-Rāzî merelevansikan keyakinan ilmiah dengan kebenaran ilmiah di dalam tafsirnya. Ketiga; Ar-Rāzî ingin menegaskan sesungguhnya studi balagah dan filsafat bisa dijadikan sebagai materi tafsîr, serta digunakan untuk menakwil ayat-ayat Al-Qur'ān, selama berdasarkan kepada kaidah-kaidah yang jelas, yaitu kaidah Ahlu Sunnah Wal Jama'ah. ${ }^{39}$

\footnotetext{
${ }^{36}$ Manna' Kholil Al-Qotton, Mabāhis fì 'Ulūm Al-Qur'ān, h. 367.

${ }^{37}$ Muhammad Ali Ayazi, Al-Mufasirūn Hayātuhum wa Manhājuhum, h. 652.

${ }^{38}$ Ibid, h. 655 . ${ }^{39}$ Ibid.
} 
Walaupun Imām Fakhruddîn Ar-Rāzî adalah seorang 'ulama yang menguasai berbagai disiplin ilmu secara komprehensif, akan tetapi dalam penulisan tafsîr Mafātîhul Ghaib beliau tidak pernah berdiri sendiri terhadap pengetahuannya, melainkan tetap merujuk kepada sumber-sumber yang șahîh. Sehingga isi dari tafsîr Mafātîhul Ghaib karya Ar-Rāzî dapat dipertanggung jawabkan secara ilmiah.

\section{Metode Penelitian}

Penelitian ini menggunakan metode analisis deskriptif yakni suatu metode yang menganalisis data suatu objek kajian, kemudian mendeksripsikannya sesuai hasil analisis data tersebut.

\section{Pembahasan}

Pada dasarnya di dalam tafsîr Al-Rāzî mengandung banyak sekali nilainilai multikultural, hal ini dibuktikan dengan dijadikannya tafsîr Ar-Rāzî sebagai rujukan dari berbagai golongan. Namun dari sekian banyak nilai-nilai multikultural yang ada di dalam tafsîr Ar-Rāzî, terdapat tiga nilai yang perlu diberikan perhatian lebih, karena tiga nilai ini dianggap mewakili dari berbagai nilai multikultural yang diajarkan oleh Imām Fakhruddîn Ar-Rāzî. Selain itu, tiga nilai ini juga berfungsi secara langsung pada pembelajaran yang dilakukan di dalam kelas. Nilai-nilai tersebut yaitu: (1). Belajar hidup dalam perbedaan; (2). Kebebasan berpendapat atau terbuka dalam berpikir, (3). Saling menghargai dan menghormati.

Adapun pendekatan pembelajaran yang akan dikembangkan dengan menginternalisasi ketiga nilai ini adalah pendekatan pembelajaran yang biasa digunakan dalam pembelajaran tafsir, yaitu pendekatan pembelajaran dengan ciriciri: (1). Peserta didik adalah penerima informasi secara pasif, dimana peserta didik menerima pengetahuan dari guru dan pengetahuan diasumsinya sebagai badan dari informasi dan keterampilan yang dimiliki sesuai dengan standar; (2). Belajar secara individual; (3). Pembelajaran sangat abstrak dan teoritis; (4). erilaku dibangun atas kebiasaan; (5). Kebenaran bersifat absolut dan pengetahuan bersifat final; (6). Guru adalah penentu jalannya proses pembelajaran; (7). Perilaku baik berdasarkan motivasi ekstrinsik; (8). Interaksi di antara peserta didik 
kurang; (9). Guru sering bertindak memperhatikan proses kelompok yang terjadi dalam kelompok-kelompok belajar. ${ }^{40}$

Apabila tiga nilai multikultural yang dijelaskan oleh Imām Ar-Rāzî ini dimasukkan kedalam pendekatan pembelajaran ini, maka akan dihasilkan pembelajaran yang multikultural dengan ciri: (1). Peserta didik tidak lagi menerima informasi secara pasif, akan tetapi peserta didik bisa bersifat aktif di dalam pembelajaran, karena peserta didik diberikan kebebasan berpendapat sesuai dengan wawasan keilmuan yang dimilikinya, dan guru di sini berfungsi sebagai filter pengetahuan. Jadi, pengetahuan tidak hanya datang dari seorang guru, tapi dari segala hal yang termasuk dalam proses dan penunjang pembelajaran. Hal ini sesuai dengan apa yang diaplikasikan oleh Imām Al-Rāzî di dalam tafsîrnya, yakni mengutip berbagai pendapat dalam menafsirkan suatu ayat, akan tetapi berbagai pendapat ini tetap diberikan keterangan pendapat mana yang lebih rajîh atau sesuai dengan keyakinan Ahlu Sunnah wal Jama'ah, ${ }^{41}$ seperti ketika menafsirkan surah Al-Baqarah ayat 256:

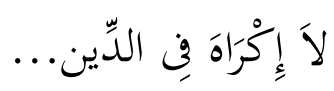

Terjemahnya:

Tidak ada paksaan di dalam agama...

Dijelaskan makna ayat ini menurut Mu'tazilah dan Jabariyah, namun kesemua penjelasan tersebut difilter dengan keterangan dari Ahlu Sunnah wal Jama' $a h^{42}$

Belajar secara berjama'ah, berbeda dengan pembelajaran konvensional yang menjadikan seorang peserta didik hanya belajar secara individu dan menanamkan bahwa keberhasilan akan datang apabila seorang individu bersungguh-sungguh secara mandiri dalam belajarnya. ${ }^{43}$ Dengan pembelajaran secara berjama'ah, seorang peserta didik akan berusaha berinteraksi dengan

\footnotetext{
${ }^{40}$ Suyono dan Hariyanto, Belajar dan Pembelajaran: Teori dan Konsep Dasar, Bandung: PT. Remaja Rosdakarya, 2011, Cet. ke-2, h.11.

${ }^{41}$ Muhammad Husein Adz-Dzahabi, At-Tafsîr wal Mufassîrūn, Juz. 1, h. 209-210.

${ }^{42}$ Muḥammad bin Umar, Mafātîhul Ghaib, Juz. 7, h. 13-14.

${ }^{43}$ Suyono dan Hariyanto, Belajar dan Pembelajaran: Teori dan Konsep Dasar, h. 10-11.
} 
peserta didik yang lain dalam proses pembelajaran. Hal ini tentunya menimbulkan dampak positif yaitu terjadinya transfer informasi dari peserta didik yang memiliki wawasan luas kepada peserta didik yang berwawasan terbatas, sehingga kesenjangan pengetahuan antara peserta didik dapat diminimalisir. Disamping itu, belajar secara berjama'ah juga dapat meningkatkan motivasi belajar peserta didik, berbeda dengan belajar secara individu yang hanya mengandalkan kekuatan pribadi, dengan belajar secara berjama'ah peserta didik yang bersifat malas akan lebih termotivasi apabila terdapat peserta didik lain yang lebih giat dari pada dirinya. ${ }^{44}$ Apabila kondisi jama'ah dalam pembelajaran sudah tercipta, maka sikap saling menghargai dan kasih sayang akan muncul dengan sendirinya, sehingga kompetensi yang tidak sehat antara peserta didik tidak akan terjadi. Kegiatan ini sejalan dengan apa yang dijelaskan oleh Imām Ar-Rāzî di dalam tafsîrnya dari kata:

Terjemahnya:

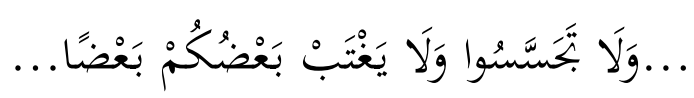

Dan janganlah mencari-cari keburukan orang serta menggunjingkan satu sama lain.

Maksudnya adalah diharamkan untuk mencari-cari keburukan orang lain, akan tetapi sebaliknya bersikap menghargai dan menyayangi orang lain merupakan sesuatu yang mutlak. ${ }^{45}$

Pembelajaran yang dilakukan tidak hanya dilakukan secara abstrak dan teoritis, akan tetapi lebih kepada mengaitkan teori kepada hal-hal yang ada disekitar. Pembelajaran dengan metode ini tidak akan terlaksana tanpa adanya sikap terbuka dalam berpikir. Sikap terbuka dalam berpikir ini telah dipraktekkan Imām Ar-Rāzî pada kegiatan penafsirannya, dengan cara memasukkan berbagai macam disiplin ilmu pengetahuan sebagai alat penafsirannya, sehingga kitab tafsîr Mafātîhul Ghaib berbeda dengan kitab-kitab tafsîr yang lain. Apabila kitab-kitab

\footnotetext{
${ }^{44}$ Abu Bakar Fahmi, Menit untuk Anakku, h. 96.

${ }^{45}$ Muḥammad bin Umar, Mafātîḥul Ghaib, Juz. 27, h. 137.
} 
tafsîr pada umumnya berisikan tentang dokrin-dokrin agama, maka kitab tafsîr Mafātîhul Ghaib menjelaskan firman-firman Allah seperti ensiklopedia. ${ }^{46}$

Perilaku yang dipraktekkan dibangun atas dasar menghargai pada nilainilai multikultural, seperti belajar hidup dalam perbedaan, kebebasan berpendapat, dan saling menghargai. Hal ini pula yang sudah dilakukan Imām Ar-Rāzî dalam kehidupannya, beliau tidak pernah membeda-bedakan para murid yang belajar kepadanya, baik dari golongan Asy'ariyah, Karamiyyah, Mu'tazilah, Syi'ah dan lain-lain, sehingga para muridnya menerima apa yang disampaikan oleh Imām ArRāzî. ${ }^{47}$ Pada pembelajaran yang didasari pada pendekatan memberi kebebasan dalam berpendapat atau terbuka dalam berpikir, berasumsi bahwa selain ketentuan Allah yang bersifat qothi', maka semua hal masih disifati dzanni. Hal ini sesuai dengan apa yang diajarkan oleh Imām Fakhruddîn Ar-Rāzî, bahwa beliau mengajarkan kebebasan dalam menyampaikan pendapat, kebebasan ini menurut beliau juga dianjurkan Allah di dalam Al-Qur'an pada surah Al-Baqarah ayat 256:

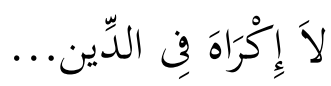

Terjemahnya:

Tidak ada paksaan di dalam agama...

Pada ayat ini sudah sangat jelas tidak ada pemaksaan terhadap sesuatu, bahkan terhadap sesuatu yang salah sekalipun, tidak diperkenankan memaksakan kebenaran kepadanya. ${ }^{48}$ Tidak berbeda dengan apa yang dilakukan oleh seorang guru di dalam kelasnya, karena seorang guru dituntut untuk memberikan kebebasan kepada anak didiknya mengungkapkan pendapatnya, terlebih pada permasalahan teologi dan fiqih, yang di dalamnya banyak terdapat perbedaan.

Pendekatan pembelajaran yang di dasari atas asas saling menghargai, akan menciptakan suatu kondisi di mana seorang guru tidak mutlak menjadi raja didalam kelas. Karena bisa jadi suatu saat guru melakukan kesalahan dalam pembelajarannya, contohnya dalam proses memberi harakat dan menterjemahkan

\footnotetext{
${ }^{46}$ Muhammad Husein Adz-Dzahabi, At-Tafsîr wal Mufassirūn, h. 210.

${ }^{47}$ Muhammad bin Umar, Mafātîhul Ghaib, Juz. 1, h. 5.

${ }^{48}$ Ibid., Juz. 7, h. 13-14.
} 
teks-teks dari kitab-kitab tafsir klasik, tidak serta merta apa yang disampaikan guru baik berupa harakat maupun makna sesuai dengan apa yang dimaksud teks sebenarnya, dan bisa jadi harakat diberikan oleh peserta didik dan makna yang disampaikan lebih tepat. Hal ini sangat bersesuaian dengan apa yang dijelaskan oleh Imām Fakhruddîn Ar-Rāzî pada tafsîr surah As-Syuura ayat 15:

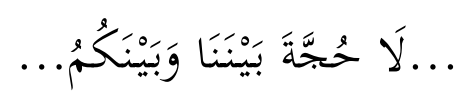

Artinya:

Tidak ada pertentangan antara kami dan kamu

Dengan keterangan:

$$
\text { لا يجوز تحريم المحاجة }
$$

Terjemahnya:

Tidak diperkenankan melarang orang lain berpendapat. ${ }^{49}$

Pada pembelajaran dengan pendekatan saling menghargai, guru menciptakan suatu kondisi di mana peserta didik berusaha mempraktekkan sikap saling menghargai dan menyayangi murni atas dasar kesadaran, tanpa berpikir bahwa perilaku tersebut akan mendapatkan penilaian ataupun tidak. Karena buah dari apa yang dipraktekkan peserta didik tidak hanya berupa penilaian dari guru, akan tetapi lebih dari itu penilaian dari Tuhan dan lingkungan. Di-samping itu sikap menghargai dan kasih sayang merupakan suatu sikap yang mutlak untuk dilakukan, seperti kemutlakan untuk meninggalkan sikap mencari-cari keburukan dan menggunjing orang lain, ${ }^{50}$ sebagaimana yang dijelaskan Imām Fakhruddîn Ar-Rāzî pada tafsîr surah Al-Hujurat ayat 12:

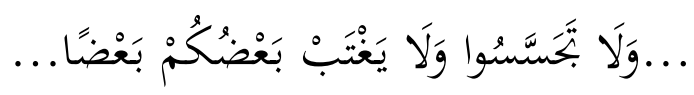

Terjemahnya:

Dan janganlah mencari-cari keburukan orang serta menggunjingkan satu sama lain.

${ }^{49}$ Ibid., Juz. 27, h. 137.

${ }^{50}$ Ibid., Juz. 28, h. 115. 
Kata لا لا النّاهيّة yang menunjukkan kepada hukum haram. Interaksi antara peserta didik dibangun tanpa ada pengkotak-kotakan derajat, tanpa dibedakan warna kulit, suku, derajat sosial, tingkat intelejensi, kegiatan ekstra yang diikuti dan lain sebagainya. Sebab menurut Imām Fakhruddîn Ar-Rāzî bahwa manusia pada mulanya berasal dari نفس واحدة yang artinya diri yang satu, kemudian Allah jadikan berbeda keadaan antara satu dan yang lain, akan tetapi keadaan ini tidak menjadikan yang satu lebih mulia dari yang lain. ${ }^{51}$ Adapun hikmah dari perbedaan yang diciptakan Allah ini adalah agar manusia lebih mudah mengenal manusia yang lain. Guru tidak diperkenankan hanya mengawasi kelompok belajar tertentu, akan tetapi seluruh kelompok belajar hendaknya diperhatikan dengan seksama. Hal ini yang dipraktekkan oleh Imām Fakhruddîn Ar-Rāzî dalam pembelajaran tafsîrnya, dengan memperhatikan semua muridnya tanpa memandang apa latar belakang golongannya. ${ }^{52}$

\section{E. Kesimpulan}

Berdasarkan apa yang telah dipaparkan, ditarik kesimpulan bahwa menurut Imām Fakhruddîn Al-Rāzî, belajar hidup dalam perbedaan adalah suatu sikap yang mesti ada di dalam diri setiap orang, sebab Allah SWT telah menetapkan bahwa manusia akan selalu berbeda dalam berbagai hal, termasuk di antaranya agama, akhlaq ataupun perbuatan. Kebebasan berpendapat adalah salah satu hak yang diberikan Allah kepada manusia, oleh karena itu Allah SWT tidak pernah memaksakan kehendak-Nya kepada manusia, termasuk di antaranya dalam hal keyakinan. Saling menghargai dan menghormati orang lain adalah satu sikap yang terbangun dari perbuatan menghindari buruk sangka, mencari-cari keburukan orang lain, dan menggunjing satu sama lain. Di samping itu, memberikan kebebasan kepada orang lain dalam menyampaikan alasan juga merupakan aplikasi dari sikap menghargai dan menghormati orang lain. Hasil dari internalisasi nilai-nilai multikultural yang telah dikemukakan oleh Imām Fakhruddîn Ar-Rāzî pada pendekatan pembelajaran tafsîr adalah pendekatan pembelajaran yang memiliki ciri-ciri: peserta didik tidak lagi menjadi penerima

\footnotetext{
${ }^{51}$ Ibid., Juz. 9, h. 131.

${ }^{52}$ Ibid., Juz. 1, h. 5.
} 
informasi pasif dalam pembelajaran; kegiatan belajar mengarahkan kepada keaktifan secara berjama'ah; kegiatan belajar tidak hanya dilakukan secara abstrak dan teoritis; perilaku dibangun atas dasar menghargai nilai-nilai perbedaan; guru tidak menjadi seorang raja diktator di dalam kelas; memberikan kesempatan untuk mengutarakan pendapat; akhlaqul kharimah diterapkan atas dasar kesadaran; tidak ada diskriminasi dalam interaksi; semua kelompok belajar mendapatkan perhatian yang sama.

\section{Daftar Pustaka}

Abdurrahman, Hafidz, Ulumul Qur'an Praktis, Bogor: Pustaka Utama, 2003.

Adz-Dzahabi, Muhammad Husein, At-Tafsîr wal Mufassîrūn, Qohiroh: Maktabah Wahbah, 1396H/ 1976M, Juz. 1.

Al-Gazali, Muhammad, Ihya Ulūmuddîn, Beirut: Dar Al-Ma'rifah, t.th, Juz. 1.

Al-Hasan, 'Ali, Al-Manâr, Beirut: Dâr Al-Fikr Al-'Arabi, 1998.

Al-Jurjâni, At-Ta'rîfât, Beirut: Dâr Al-Bayân li At-Turâts, t.th.

Al-Qardhawi, Yusuf, Aqidah Salaf dan Khalaf, Jakarta: Pustaka Al-Kautsar, 2006, Cet. ke-I.

Al-Qotton, Manna' Kholil, Mabāhis fî 'Ulūm Al-Qur'ān, Riyadh: Mansurat Al'asri Al-Hadist, $1411 \mathrm{H}$.

An-Nabhâni, Taqiyuddîn, Syakhshiyyah Islamiyyah, Bogor: Pustaka Thariqul Izzah, 2003, cet. I, juz I.

Ar-Razi, Muhammad, Mafātîhul Ghaib, Beirut: Dar Al-Kotob Al-Ilmiyah, 1434 H/ 2013 M, Juz. 1.

As-Shabuni, Muhammad Ali, At-Tibyan Fî 'Ulūmil Qur'ān, Karachi: Maktabah Al-Bushra, 1432H/ 2011M.

As-Suyuṭ̂i, Jalaluddin, Jam'ul Jawāmi', Mesir: Dar As-Sā'adah Lit Ṭaba'ah, 1426 H/ 2005 M, Juz. 2.

Banna, Jamalul, At-Ta'addudiyyah Fî Mujtama' Islamî, Qohiroh: Dar Al-Fikr Al-Islamiy, 2001.

FM, Muhammad Yusri, "Prinsip Pendidikan Multikulturalisme dalam Ajaran Agama-agama di Indonesia", Jurnal Kependidikan Islam Jurusan Kependidikan Islam Fakultas Tarbiyah UIN Sunan Kalijaga Yogyakarta, Vol. 3, No. 2, 2008.

Hakim, Abdul Hamid, Mabād̄̄ Awwalîyah, Jakarta: Maktabah Sa'adiyyah Putra, Tt.

Hanum, Farida dan Setya Raharja, "Pengembangan Model Pembelajaran 
Pendidikan Multikultural Menggunakan Modul Sebagai Suplemen Pelajaran IPS di Sekolah Dasar", Jurnal Penelitian Ilmu Pendidikan, Vol. 04, No. 2, 2011.

Mahfud, Choirul, Pendidikan Multikultural, Yogyakarta: Pustaka Pelajar, 2008.

Nasir, Sahilun A., Pemikiran Kalam (Teologi Islam): Sejarah, Ajaran dan Perkembangannya, Jakarta: Raja Grafindo Persada, 2010, Cet. ke-I.

Pidarta, Made, Manajemen Pendidikan Indonesia, Jakarta: Bina Aksara, 1988, Cet. 1 .

Suyono dan Hariyanto, Belajar dan Pembelajaran: Teori dan Konsep Dasar, Bandung: PT. Remaja Rosdakarya, 2011, Cet. ke-2.

Tilaar, H.A.R, Multikulturalisme: Tantangan-tantangan Global Masa Depan dalam Transformasi Pendidikan Nasional, Jakarta: Grasindo, 2004.

Yamin, Martinis, Profesionalisasi Guru dan Implementasi KTSP, Jakarta: Gaung Persada Press, 2007.

Zuhaili, Wahbah, Al-Mausū'atul Qur'āniyyatul Muyassarah, Depok: Gema Insani, 1428 H/ 2007 M, Cet. ke-1. 